\title{
FEATURES OF THE OFFER IN THE DISTRIBUTION AREA. COMPARATIVE ANALYSIS ON THE EXAMPLE OF DAIRY COOPERATIVES IN THE MALOPOLSKIE AND ŚWIĘTOKRZYSKIE VOIVODESHIPS
}

\author{
Izabela KONIECZNA \\ Jan Kochanowski University in Kielce, Faculty of Law and Social Sciences, Department of Management; \\ irud@interia.pl, ORCID: 0000-0002-3632-3245
}

Purpose: The first purpose of this article is to identify and compare the validity of features of the offer for the customer in the area of distribution from the point of view of dairy cooperatives from Poland from the Świętokrzyskie and Małopolskie provinces, which are adjacent to each other.

Design/methodology/approach: Direct interviews using a questionnaire survey were conducted among representatives of cooperatives representing $41 \%$ of the population, which resulted from the willingness to participate in the survey.

Findings: The analysis of the research results, taking into account the mean for all customers, show that the indicated features of the offer for the customer in the distribution area were considered by cooperatives from both provinces as very important (there was only one feature that was not indicated by all cooperatives).

Originality/value: The comparison of the validity of features of the offer for the customer in the area of distribution of selected cooperatives from two different voivodeships.

Keywords: Distribution, value creation, features of the offer, cooperatives.

Category of the paper: Research paper, case study.

\section{Introduction}

The main distribution's goal is to transfer finite goods from production to purchase and consumption (Burda, 2012). Distribution involves taking steps to deliver the product, along with the ownership (in the case of sale) or the right to use the product (in the case of lease), from the place of manufacture to the final buyer (Kłeczek, 1992). This transfer implies a series of specific activities, among others there can be distinguished the location of the outlets, the establishment of the ways to supply goods, the creation of the system for the goods' transfer, handling, transportation and insurance as well as the usage of certain methods to exhibit, present 
and sell the goods (Burda, 2012). It is known that the main functions of distribution logistics are the following 1) definition of consumer demand and its satisfaction; 2) establishment of economic relations on the supply of goods, rendering of services to consumers; 3) building an organizational scheme of distribution channels; 4) accumulation, sorting and arrangement of stocks of the finished products; 5) transportation of the finished products, returnable containers; 6) consolidation and dispersal of goods; 7) choice of the rational forms of physical distribution and trade organization; 8) maintaining quality standards of the finished products and logistics services; 9) monitoring and information support of the distribution (Lukinykh, Lukinykh, 2015).

The key role that distribution plays is satisfying a firm's customer and achieving a profit for the firm (Burnett, 2010, p. 282). Especially since the volume of sales revenues is largely influenced by the distribution policy, under which decisions are made to choose the sales route and outlets (e.g. the choice of own branches, sales agents or completely independent sales plants) and decisions about distributing products in a network of possible outlets (degree of distribution, network density, etc.) (Sierpińska, Jachna, 2007). The market analysis needs to identify who the customer is and what criteria they use to judge a product offering (Drummond et al., 2008). This allows an organization to understand the needs of the customer, and identifying changing trends in consumer behavior may begin to signal potential market developments and opportunities (Drummond et al., 2008). It is possible when the distribution network is efficiently managed (Blythe, 2005). The design of the distribution network is influenced by the marketing policy of the manufacturer (Große-Brockhoff, Klumpp, Krome, 2011), especially since the larger and more geographically dispersed is the market, the greater is the need to use the services of intermediaries due to the high costs associated with directly serving numerous customers (Altkorn, 2004). In this case goods come down the channel and information goes up (Blythe, 2005), because producers rarely directly deliver products to final consumers instead they are just one segment in whole distribution channel (Vučemilović, 2015). There are three levels of distribution intensity: intensive distribution (when the manufacturer offers end buyers a certain type of product through as many merchants as possible in a specific geographic area), selective distribution (when the manufacturer offers end buyers a certain type of product through selected commercial intermediaries in a specific geographic area), exclusive distribution (when the manufacturer offers end buyers a specific type of product through one selected commercial broker in a specific geographic area) (Kłeczek, 1992). The choice of participants in the distribution channel is considered as one of the critical decisions for the manufacturer. The basic factors to be considered when making a decision are: 1. funding and credit strength, 2. the power of promotion and sales of the distributor, 3. ability to maintain stocks and storage locations, and 4. principles of management (Krawczyk, 2000). Therefore company will conduct profitable business only if all companies involved in distribution channel are profitable (Vučemilović, 2015). Deciding, which is the best distribution strategy for a particular product of a company can make an enormous impact on the success of 
that company (Lourenço, 2005), especially since distribution channel can also be a way of achieving advantage in relation to competition (Vučemilović 2015).

Therefore, the purpose of this article is to identify and compare the validity of features of the offer for the customer in the area of distribution from the point of view of dairy cooperatives from Poland from the Świętokrzyskie and Małopolskie provinces, which are adjacent to each other.

\section{Methods}

The subject of the research carried out among representatives of dairy cooperatives from the Świętokrzyskie and Małopolskie provinces was an assessment of the validity of the offer's features in the distribution area. There was used purposeful selection of the sample. Direct interviews using a questionnaire survey were conducted among representatives of cooperatives representing $41 \%$ of the population, which resulted from the willingness to participate in the survey. Respondents had to indicate which features of the offer are important for different customers' groups: consumers, enterprises - users (gastronomy), wholesalers, independent retail grocery stores, large and local shopping chains, agents involved in the food trade, other dairies and other institutional buyers. They had to assess such features/elements of the offer as: differentiation of the distribution method, ensuring easy access to the product on the market, ensuring a convenient time to purchase the product, ensuring a convenient place to purchase the product, the ability to purchase products via the internet, product delivery time, timely deliveries, frequency of deliveries, flexibility of delivery in terms of time, size, range and delivery method, reliability of deliveries in terms of time, quantity and quality of delivered products, completeness of deliveries - compliance of delivery with the order, the possibility of quick communication between the buyer and the bidder (eg on-line). The assessment was made on a scale of 1 to 5 , where 5 meant that the offer feature is extremely important, 4 - important, 3 - quite important, 2 - little important, and 1 - completely unimportant. If the cooperative was not able to assess or did not have specific clients, 0 was inserted - not applicable. The research results are presented in Table 1 and 2. Additionally, these results are enhanced by the analysis of the financial ratios, which are shown in Table 3. 


\section{Results}

Table 1 shows that there are no agents involved in the food trade, other dairies and other institutional buyers among the cooperatives from both provinces customers. Additionally, among customers of cooperatives from Świętokrzyskie Province there are no independent grocery stores and large retail chains.

Table 1.

The validity of features of the offer for the customer in the distribution area for different types of customers

\begin{tabular}{|c|c|c|c|c|c|c|c|c|c|c|c|}
\hline \multirow{2}{*}{\multicolumn{3}{|c|}{ Features/elements of the offer }} & \multirow{3}{*}{ 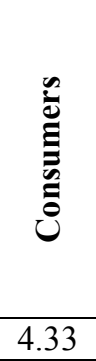 } & \multirow{3}{*}{ 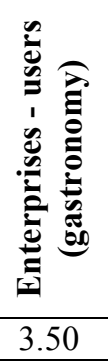 } & \multirow{3}{*}{ 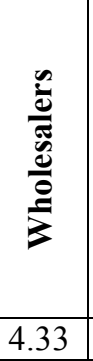 } & \multirow{3}{*}{ 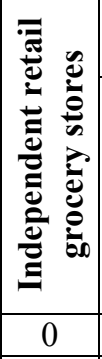 } & \multicolumn{2}{|c|}{$\begin{array}{c}\text { Shopping } \\
\text { chains }\end{array}$} & \multirow{2}{*}{ 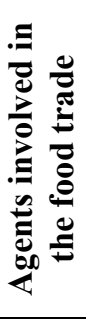 } & \multirow{3}{*}{ 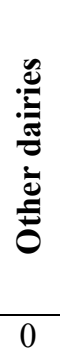 } & \multirow{3}{*}{ 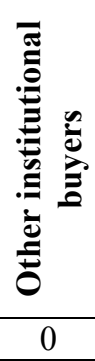 } \\
\hline & & & & & & & 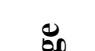 & $\equiv$ & & & \\
\hline \multirow{6}{*}{$\begin{array}{l}\text { Differentiation of } \\
\text { the distribution } \\
\text { method }\end{array}$} & \multirow{3}{*}{ Ś } & Mean & & & & & 0 & 4.33 & 0 & & \\
\hline & & Standard deviation & 0.577 & 0.707 & 0.577 & 0 & 0 & 0.577 & 0 & 0 & 0 \\
\hline & & Median & 4 & 4 & 4 & 0 & 0 & 4 & 0 & 0 & 0 \\
\hline & \multirow{3}{*}{$\mathrm{M}$} & Mean & 4.25 & 4.00 & 4.00 & 5.00 & 4.00 & 4.25 & 0 & 0 & 0 \\
\hline & & Standard deviation & 0.500 & 0.816 & 0.816 & 0.000 & 0.000 & 0.957 & 0 & 0 & 0 \\
\hline & & Median & 4 & 4 & 4 & 5 & 4 & 5 & 0 & 0 & 0 \\
\hline \multirow{6}{*}{$\begin{array}{l}\text { Ensuring easy } \\
\text { access to the } \\
\text { product on the } \\
\text { market }\end{array}$} & \multirow{3}{*}{$\dot{S}$} & Mean & 4.33 & 4.50 & 4.33 & 0 & 0 & 4.00 & 0 & 0 & 0 \\
\hline & & Standard deviation & 0.577 & 0.707 & 1.155 & 0 & 0 & 0.000 & 0 & 0 & 0 \\
\hline & & Median & 4 & 5 & 5 & 0 & 0 & 4 & 0 & 0 & 0 \\
\hline & \multirow{3}{*}{$\mathrm{M}$} & Mean & 4.50 & 4.50 & 4.00 & 4.00 & 4.00 & 3.50 & 0 & 0 & 0 \\
\hline & & Standard deviation & 0.577 & 0.577 & 0.816 & 0.000 & 0.000 & 0.577 & 0 & 0 & 0 \\
\hline & & Median & 5 & 5 & 4 & 4 & 4 & 4 & 0 & 0 & 0 \\
\hline \multirow{6}{*}{$\begin{array}{l}\text { Ensuring a } \\
\text { convenient time to } \\
\text { purchase the } \\
\text { product }\end{array}$} & \multirow{3}{*}{$\dot{S}$} & Mean & 4.00 & 5.00 & 4.00 & 0 & 0 & 4.33 & 0 & 0 & 0 \\
\hline & & Standard deviation & 0.000 & 0.000 & 0.000 & 0 & 0 & 0.577 & 0 & 0 & 0 \\
\hline & & Median & 4 & 5 & 4 & 0 & 0 & 4 & 0 & 0 & 0 \\
\hline & \multirow{3}{*}{$\mathrm{M}$} & Mean & 4.00 & 4.50 & 3.75 & 4.00 & 4.00 & 3.75 & 0 & 0 & 0 \\
\hline & & Standard deviation & 0.816 & 1.000 & 0.500 & 0.000 & 0.000 & 1.258 & 0 & 0 & 0 \\
\hline & & Median & 4 & 5 & 4 & 4 & 4 & 4 & 0 & 0 & 0 \\
\hline \multirow{6}{*}{$\begin{array}{l}\text { Ensuring a } \\
\text { convenient place } \\
\text { to purchase the } \\
\text { product }\end{array}$} & \multirow{3}{*}{$\dot{S}$} & Mean & 4.33 & 5.00 & 3.33 & 0 & 0 & 4.33 & 0 & 0 & 0 \\
\hline & & Standard deviation & 0.577 & 0.000 & 0.577 & 0 & 0 & 0.577 & 0 & 0 & 0 \\
\hline & & Median & 4 & 5 & 3 & 0 & 0 & 4 & 0 & 0 & 0 \\
\hline & \multirow{3}{*}{$\mathrm{M}$} & Mean & 4.25 & 4.00 & 4.50 & 4.00 & 3.00 & 3.75 & 0 & 0 & 0 \\
\hline & & Standard deviation & 0.500 & 0.000 & 0.577 & 0.000 & 0.000 & 0.957 & 0 & 0 & 0 \\
\hline & & Median & 4 & 4 & 5 & 4 & 3 & 4 & 0 & 0 & 0 \\
\hline \multirow{6}{*}{$\begin{array}{l}\text { The ability to } \\
\text { purchase products } \\
\text { via the Internet }\end{array}$} & \multirow{3}{*}{$\dot{S}$} & Mean & 4.00 & 4.50 & 3.67 & 0 & 0 & 4.00 & 0 & 0 & 0 \\
\hline & & Standard deviation & 0.000 & 0.707 & 0.577 & 0 & 0 & 0.000 & 0 & 0 & 0 \\
\hline & & Median & 4 & 5 & 4 & 0 & 0 & 4 & 0 & 0 & 0 \\
\hline & \multirow{3}{*}{$\mathrm{M}$} & Mean & 4.50 & 4.25 & 4.50 & 5.00 & 2.00 & 3.75 & 0 & 0 & 0 \\
\hline & & Standard deviation & 0.577 & 0.500 & 0.577 & 0.000 & 0.000 & 1.258 & 0 & 0 & 0 \\
\hline & & Median & 5 & 4 & 5 & 5 & 2 & 4 & 0 & 0 & 0 \\
\hline & & Mean & 4.33 & 4.00 & 4.00 & 0 & 0 & 4.00 & 0 & 0 & 0 \\
\hline & Ś & Standard deviation & 0.577 & 0.000 & 0.000 & 0 & 0 & 1.000 & 0 & 0 & 0 \\
\hline Product delivery & & Median & 4 & 4 & 4 & 0 & 0 & 4 & 0 & 0 & 0 \\
\hline time & & Mean & 4.00 & 4.25 & 4.00 & 4.00 & 4.00 & 4.00 & 0 & 0 & 0 \\
\hline & $\mathrm{M}$ & Standard deviation & 0.816 & 0.500 & 0.816 & 0.000 & 0.000 & 0.816 & 0 & 0 & 0 \\
\hline & & Median & 4 & 4 & 4 & 4 & 4 & 4 & 0 & 0 & 0 \\
\hline
\end{tabular}


Cont. Table 1.

\begin{tabular}{|c|c|c|c|c|c|c|c|c|c|c|c|}
\hline \multirow{6}{*}{ Timely deliveries } & & Mean & 4.33 & 4.50 & 4.67 & 0 & 0 & 3.67 & 0 & 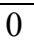 & 0 \\
\hline & $\dot{S}$ & Standard deviation & 0.577 & 0.707 & 0.577 & 0 & 0 & 1.528 & 0 & 0 & 0 \\
\hline & & Median & 4 & 5 & 5 & 0 & 0 & 4 & 0 & 0 & 0 \\
\hline & & Mean & 4.25 & 3.50 & 3.75 & 4.00 & 4.00 & 4.00 & 0 & 0 & 0 \\
\hline & $\mathrm{M}$ & Standard deviation & 0.500 & 0.577 & 1.258 & 0.000 & 0.000 & 0.000 & 0 & 0 & 0 \\
\hline & & Median & 4 & 4 & 4 & 4 & 4 & 4 & 0 & 0 & 0 \\
\hline \multirow{6}{*}{$\begin{array}{l}\text { Frequency of } \\
\text { deliveries }\end{array}$} & & Mean & 4.33 & 4.00 & 4.33 & 0 & 0 & 4.00 & 0 & 0 & 0 \\
\hline & $\dot{S}$ & Standard deviation & 0.577 & 0.000 & 0.577 & 0 & 0 & 0.000 & 0 & 0 & 0 \\
\hline & & Median & 4 & 4 & 4 & 0 & 0 & 4 & 0 & 0 & 0 \\
\hline & & Mean & 4.25 & 4.50 & 4.00 & 4.00 & 4.00 & 4.25 & 0 & 0 & 0 \\
\hline & $\mathrm{M}$ & Standard deviation & 0.957 & 0.577 & 0.000 & 0.000 & 0.000 & 0.500 & 0 & 0 & 0 \\
\hline & & Median & 5 & 5 & 4 & 4 & 4 & 4 & 0 & 0 & 0 \\
\hline \multirow{6}{*}{$\begin{array}{l}\text { Flexibility of } \\
\text { delivery in terms } \\
\text { of time, size, } \\
\text { range and delivery } \\
\text { method }\end{array}$} & & Mean & 4.33 & 3.50 & 3.67 & 0 & 0 & 4.67 & 0 & 0 & 0 \\
\hline & Ś & Standard deviation & 0.577 & 0.707 & 0.577 & 0 & 0 & 0.577 & 0 & 0 & 0 \\
\hline & & Median & 4 & 4 & 4 & 0 & 0 & 5 & 0 & J & 0 \\
\hline & & Mean & 4.00 & 4.50 & 4.25 & 5.00 & 5.00 & 4.25 & 0 & 0 & 0 \\
\hline & $\mathrm{M}$ & Standard deviation & 0.816 & 0.577 & 0.500 & 0.000 & 0.000 & 0.500 & 0 & 0 & 0 \\
\hline & & Median & 4 & 5 & 4 & 5 & 5 & 4 & 0 & 0 & 0 \\
\hline \multirow{6}{*}{$\begin{array}{l}\text { Reliability of } \\
\text { deliveries in terms } \\
\text { of time, quantity } \\
\text { and quality of } \\
\text { delivered products }\end{array}$} & & Mean & 4.00 & 4.00 & 4.00 & 0 & 0 & 3.67 & 0 & 0 & 0 \\
\hline & Ś & Standard deviation & 0.000 & 0.000 & 1.000 & 0 & 0 & 0.577 & 0 & 0 & 0 \\
\hline & & Median & 4 & 4 & 4 & 0 & 0 & 4 & 0 & 0 & 0 \\
\hline & & Mean & 4.00 & 3.50 & 3.25 & 4.00 & 3.00 & 3.75 & 0 & 0 & 0 \\
\hline & $\mathrm{M}$ & Standard deviation & 0.816 & 0.577 & 0.500 & 0.000 & 0.000 & 0.500 & 0 & 0 & 0 \\
\hline & & Median & 4 & 4 & 3 & 4 & 3 & 4 & 0 & 0 & 0 \\
\hline \multirow{6}{*}{$\begin{array}{l}\text { Completeness of } \\
\text { deliveries - } \\
\text { compliance of } \\
\text { delivery with the } \\
\text { order }\end{array}$} & & Mean & 4.00 & 4.50 & 3.67 & 0 & 0 & 4.67 & 0 & 0 & 0 \\
\hline & S & Standard deviation & 0.000 & 0.707 & 0.577 & 0 & 0 & 0.577 & 0 & 0 & 0 \\
\hline & & Median & 4 & 5 & 4 & 0 & 0 & 5 & 0 & 0 & 0 \\
\hline & & Mean & 3.75 & 4.00 & 3.25 & 4.00 & 4.00 & 3.50 & 0 & 0 & 0 \\
\hline & $\mathrm{M}$ & Standard deviation & 0.957 & 0.816 & 0.957 & 0.000 & 0.000 & 0.577 & 0 & 0 & 0 \\
\hline & & Median & 4 & 4 & 4 & 4 & 4 & 4 & 0 & 0 & 0 \\
\hline \multirow{6}{*}{\begin{tabular}{|l|} 
The possibility of \\
quick \\
communication \\
between the buyer \\
and the bidder \\
(eg. on-line)
\end{tabular}} & & Mean & 0 & 0 & 0 & 0 & 0 & 0 & 0 & 0 & 0 \\
\hline & $\dot{S}$ & Standard deviation & 0 & 0 & 0 & 0 & 0 & 0 & 0 & 0 & 0 \\
\hline & & Median & 0 & 0 & 0 & 0 & 0 & 0 & 0 & 0 & 0 \\
\hline & & Mean & 0 & 0 & 0 & 0 & 0 & 0 & 0 & 0 & 0 \\
\hline & $\mathrm{M}$ & Standard deviation & 0 & 0 & 0 & 0 & 0 & 0 & 0 & 0 & 0 \\
\hline & & Median & 0 & 0 & 0 & 0 & 0 & 0 & 0 & 0 & 0 \\
\hline
\end{tabular}

Scale: $1-5$, where 5 - extremely important, 4 - very important, 3 - quite important, 2 - little important, 1 - completely unimportant, 0 - not applicable. Ś - Świętokrzyskie Province; M - Małopolskie Province.

Source: own work and (Konieczna, 2014).

Table 2.

The validity of features of the offer for the customer in the distribution area for all customers - an average rating

\begin{tabular}{|l|c|c|}
\hline \multicolumn{1}{|c|}{ Features/elements of the offer } & $\begin{array}{c}\text { Świętokrzyskie } \\
\text { Province }\end{array}$ & $\begin{array}{c}\text { Malopolskie } \\
\text { Province }\end{array}$ \\
\hline Differentiation of the distribution method & 4.12 & 4.25 \\
\hline Ensuring easy access to the product on the market & 4.29 & 4.08 \\
\hline Ensuring a convenient time to purchase the product & 4.33 & 4.00 \\
\hline Ensuring a convenient place to purchase the product & 4.25 & 3.92 \\
\hline The ability to purchase products via the Internet & 4.04 & 4.00 \\
\hline Product delivery time & 4.08 & 4.04 \\
\hline Timely deliveries & 4.29 & 3.92 \\
\hline Frequency of deliveries & 4.17 & 4.17 \\
\hline
\end{tabular}


Cont. table 2.

\begin{tabular}{|l|c|c|}
\hline Flexibility of delivery in terms of time, size, range and delivery method & 4.04 & 4.50 \\
\hline $\begin{array}{l}\text { Reliability of deliveries in terms of time, quantity and quality of delivered } \\
\text { products }\end{array}$ & 3.92 & 3.58 \\
\hline Completeness of deliveries - compliance of delivery with the order & 4.21 & 3.75 \\
\hline $\begin{array}{l}\text { The possibility of quick communication between the buyer and the bidder } \\
\text { (eg on-line) }\end{array}$ & 0 & 0 \\
\hline An average rating for the validity of features of the offer & $\mathbf{4 . 1 6}$ & $\mathbf{4 . 0 2}$ \\
\hline
\end{tabular}

Scale: 1-5, where 5 - extremely important, 4 - very important, 3 - quite important, 2 - little important, 1 - completely unimportant, 0 - not applicable.

Source: own work.

When analyzing the table 1 it is clear that:

- Differentiation of the distribution method is extremely important for independent retail grocery stores (mean rating is 5.00) according to cooperatives from Małopolskie Province. It is very important for consumers, wholesalers, small shopping chains, and for enterprises - users (gastronomy) (mean rating is in the range from 3.50 to 4.33) in the opinion of cooperatives from both provinces. According to cooperatives from Małopolskie Province it is also very important for large shopping chains (mean rating is 4.00).

- Ensuring easy access to the product on the market is extremely important for enterprises - users (gastronomy) according to cooperatives from both provinces, and for consumers in opinion of cooperatives from Małopolskie Province (mean rating is 4.50). It is very important for wholesalers and small shopping chains (mean rating is in the range from 3.50 to 4.33 ) in the opinion of cooperatives from both provinces. It is also very important for consumers according to cooperatives from Świętokrzyskie Province (mean rating is 4.33), for large shopping chains and for independent retail grocery stores (mean rating is 4.00) from Małopolskie Province.

- Ensuring a convenient time to purchase the product is extremely important for enterprises - users (gastronomy) (mean rating is in the range from 4.50 to 5.00) and very important for consumers, wholesalers and small shopping chains (mean rating is in the range from 3.75 to 4.33 ) in the opinion of cooperatives from both provinces. It is also very important for independent retail grocery stores, and large shopping chains (mean rating is 4.00) according to cooperatives from Małopolskie Province.

- Ensuring a convenient place to purchase the product is extremely important for enterprises - users (gastronomy) (mean rating is 5.00) according to cooperatives from Świętokrzyskie Province, and for wholesalers (mean rating is 4.50) in the opinion of cooperatives from Małopolskie Province. It is very important for consumers and small shopping chains (mean rating is in the range from 3.75 to 4.33 ) according to cooperatives from both provinces, and for independent retail grocery stores, and enterprises - users (gastronomy) (mean rating is 4.00) in the opinion of cooperatives from Małopolskie Province. It is also quite important for wholesalers (mean rating is 3.33) according to cooperatives from Świętokrzyskie Province, and for large shopping chains (mean rating is 4.00) in the opinion of cooperatives from Małopolskie Province. 
- The ability to purchase products via the Internet is extremely important for independent retail grocery stores (mean rating is 5.00), consumers, and wholesalers according to cooperatives from Małopolskie Province, and for enterprises - users (gastronomy) (mean rating is 4.50) in the opinion of cooperatives from Świętokrzyskie Province. It is very important for small shopping chains (mean rating is in the range from 3.75 to 4.00) according to cooperatives from both provinces. It is also very important for enterprises - users (gastronomy) (mean rating is 4.25) in the opinion of cooperatives from Małopolskie Province, for consumers (mean rating is 4.00), and for wholesalers (mean rating is 3.67) according to cooperatives from Świętokrzyskie Province. On the other hand it is little important for large shopping chains (mean rating is 2.00).

- Product delivery time is very important for consumers (mean rating is in the range from 4.00 to 4.33 ), enterprises - users (gastronomy) (mean rating is in the range from 4.00 to 4.25), wholesalers and for small shopping chains (mean rating is 4.00) according to cooperatives from both provinces. In the opinion of cooperatives from Małopolskie Province it is also very important for independent retail grocery stores, and large shopping chains (mean rating is 4.00 ).

- Timely deliveries are extremely important for wholesalers (mean rating is 4.67), and for enterprises - users (gastronomy) (mean rating is 4.50) in the opinion of cooperatives from Świętokrzyskie Province. They are very important for consumers (mean rating is in the range from 4.25 to 4.33 ), and for small shopping chains (mean rating is in the range from 4.67 to 4.00 ) according to cooperatives from both provinces. They are also very important for independent retail grocery stores, and large shopping chains (mean rating is 4.00) in the opinion of cooperatives from Małopolskie Province.

- Frequency of deliveries is extremely important for enterprises - users (gastronomy) (mean rating is 4.50) in the opinion of cooperatives from Małopolskie Province. It is very important for consumers (mean rating is in the range from 4.25 to 4.33 ), wholesalers (mean rating is in the range from 4.00 to 4.33 ), and for small shopping chains (mean rating is in the range from 4.00 to 4.25 ) according to cooperatives from both provinces. It is also very important for enterprises - users (gastronomy) (mean rating is 4.00) according to cooperatives from Świętokrzyskie Province. In the opinion of cooperatives from Małopolskie Province it is also very important for independent retail grocery stores, and large shopping chains (mean rating is 4.00).

- Flexibility of delivery in terms of time, size, range and delivery method is considered as extremely important for independent retail grocery stores, large shopping chains (mean rating is 5.00), and enterprises - users (gastronomy) (mean rating is 4.50) according to cooperatives from Małopolskie Province. It is also extremely important for small shopping chains (mean rating is 4.67) in the opinion of cooperatives from Świętokrzyskie Province. In the opinion of cooperatives from both provinces it is also very important for consumers (mean rating is in the range from 4.00 to 4.33 ) and 
wholesalers (mean rating is in the range from 3.67 to 4.25 ). This element of the offer is also very important for enterprises - users (gastronomy) (mean rating is 3.50) according to cooperatives from Świętokrzyskie Province, and for small shopping chains (mean rating is 4.25) in the opinion of cooperatives from Małopolskie Province.

- Reliability of deliveries in terms of time, quantity and quality of delivered products is very important for consumers, enterprises - users (gastronomy), and small shopping chains (mean rating is in the range from 3.67 to 4.00 ) according to cooperatives from both provinces. It is also very important for wholesalers in the opinion of cooperatives from Świętokrzyskie Province, and for large shopping chains according to cooperatives from Małopolskie Province (mean rating is 4.00). As quite important this element is considered to be for wholesalers (mean rating is 3.25), and large shopping chains (mean rating is 3.00) in the opinion of cooperatives from Małopolskie Province.

- Completeness of deliveries - compliance of delivery with the order is considered as extremely important for enterprises - users (gastronomy), and small shopping chains (mean rating is in the range from 4.50 to 4.67 ) in the opinion of cooperatives from Świętokrzyskie Province. It is very important for consumers according to cooperatives from both provinces (mean rating is in the range from 3.75 to 4.00 ). This feature of the offer is also very important for wholesalers in the opinion of cooperatives from Świętokrzyskie Province, for enterprises - users (gastronomy), large shopping chains, and independent retail grocery stores (mean rating is in the range from 4.50 to 4.67) according to cooperatives from Małopolskie Province. It is also little important for wholesalers in the opinion of cooperatives from Małopolskie Province (mean rating is $3.25)$.

- The possibility of quick communication between the buyer and the bidder (eg on-line) is not applicable for cooperatives from both provinces.

The analysis of table 1 also shows that:

- For consumers extremely important are ensuring easy access to the product on the market, and the ability to purchase products via the Internet according to cooperatives from Małopolskie Province (mean rating is 4.50). In the same time these features of the offer are very important for consumers in the opinion of cooperatives from Świętokrzyskie Province (mean rating is in the range from 4.00 to 4.33). According to cooperatives from both provinces very important are: differentiation of the distribution method, ensuring a convenient time to purchase the product, ensuring a convenient place to purchase the product, product delivery time, timely deliveries, frequency of deliveries, flexibility of delivery in terms of time, size, range and delivery method, reliability of deliveries in terms of time, quantity and quality of delivered products, and the possibility of quick communication between the buyer and the bidder (eg on-line) (mean rating is in the range from 3.75 to 4.33 ). 
- For enterprises - users (gastronomy) extremely important are ensuring easy access to the product on the market, ensuring a convenient time to purchase the product according to cooperatives from both provinces (mean rating is in the range from 4.50 to 5.00). In opinion of the cooperatives from Świętokrzyskie province extremely important are also ensuring a convenient place to purchase the product, the ability to purchase products via the Internet, timely deliveries, and completeness of deliveries - compliance of delivery with the order whereas cooperatives from Małopolskie Province claim that extremely important are frequency of deliveries, and flexibility of delivery in terms of time, size, range and delivery method (mean rating is in the range from 4.50 to 5.00). Very important for this kind of clients are differentiation of the distribution method, product delivery time, and reliability of deliveries in terms of time, quantity and quality of delivered products in the opinion of cooperatives from both provinces (mean rating is in the range from 3.50 to 4.00 ). According to cooperatives from Świętokrzyskie Province very important are also frequency of deliveries, and flexibility of delivery in terms of time, size, range and delivery method, while in the opinion of cooperatives from Małopolskie Province very important are ensuring a convenient place to purchase the product, the ability to purchase products via the Internet, timely deliveries, and completeness of deliveries - compliance of delivery with the order (mean rating is in the range from 3.50 to 4.25 ).

- For wholesalers extremely important are ensuring a convenient place to purchase the product, and the ability to purchase products via the Internet in the opinion of cooperatives from Małopolskie Province (mean rating is 4.50), while according to cooperatives from Świętokrzyskie Province these are timely deliveries (mean rating is 4.67). As claim cooperatives from both provinces very important for wholesalers are differentiation of the distribution method, ensuring easy access to the product on the market, ensuring a convenient time to purchase the product, product delivery time, frequency of deliveries, and flexibility of delivery in terms of time, size, range and delivery method (mean rating is in the range from 3.67 to 4.33 ). In the same time according to cooperatives from Świętokrzyskie Province very important are the ability to purchase products via the Internet, reliability of deliveries in terms of time, quantity and quality of delivered products, and completeness of deliveries - compliance of delivery with the order (mean rating is in the range from 3.67 to 4.00). On the other hand very important are timely deliveries in the opinion of cooperatives from Małopolskie Province (mean rating is 3.75). As quite important is considered by cooperatives from Świętokrzyskie Province the ensuring a convenient place to purchase the product (mean rating is 3.33) and for cooperatives from Małopolskie Province the reliability of deliveries in terms of time, quantity and quality of delivered products, and completeness of deliveries - compliance of delivery with the order (mean rating is 3.25). 
- For independent retail grocery stores extremely important are differentiation of the distribution method, the ability to purchase products via the Internet, and flexibility of delivery in terms of time, size, range and delivery method in the opinion of cooperatives from Małopolskie Province (mean rating is 5.00). Other features of the offer are considered as very important according to cooperatives from Małopolskie Province (mean rating is 4.00). Cooperatives from Świętokrzyskie Province do not have such customers.

- For large shopping chains extremely important is the flexibility of delivery in terms of time, size, range and delivery method in the opinion of cooperatives from Małopolskie Province (mean rating is 5.00). Cooperatives from Małopolskie Province also claim that for large shopping chains very important are differentiation of the distribution method, ensuring easy access to the product on the market, ensuring a convenient time to purchase the product, ensuring a convenient place to purchase the product, product delivery time, timely deliveries, frequency of deliveries, and completeness of deliveries - compliance of delivery with the order (mean rating is 4.00 ), while quite important are ensuring a convenient place to purchase the product, and reliability of deliveries in terms of time, quantity and quality of delivered products (mean rating is 3.00). According to these cooperatives little important is the ability to purchase products via the Internet (mean rating is 2.00). Cooperatives from Świętokrzyskie Province do not have such customers.

- For small shopping chains extremely important are the flexibility of delivery in terms of time, size, range and delivery method, and completeness of deliveries - compliance of delivery with the order according to cooperatives from Świętokrzyskie Province (mean rating is 4.67), whereas these features of the offer in the opinion of cooperatives from Małopolskie Province are very important (mean rating is in the range from 3.50 to 4.25). Cooperatives from both provinces claim that very important for small shopping chains are other features of the offer (mean rating is in the range from 3.67 to 4.33 ).

\section{Summary}

Distribution enables to expand the value for customer by the service. The analysis of the research results, taking into account the mean for all customers, shows that the indicated features of the offer for the customer in the distribution area were considered by cooperatives from both provinces as very important (there was only one feature that was not indicated by all cooperatives). However they differ in assessment. The highest is assessed the flexibility of delivery in terms of time, size, range and delivery method (the mean assessment of the importance of a feature is 4.27), than differentiation of the distribution method, and ensuring 
easy access to the product on the market (the mean assessment of the importance of the features is 4.19), ensuring a convenient time to purchase the product, frequency of deliveries (the mean assessment of the importance of the features is 4.17), timely deliveries (the mean assessment of the importance of a feature is 4.11), ensuring a convenient place to purchase the product (the mean assessment of the importance of a feature is 4.09), product delivery time (the mean assessment of the importance of a feature is 4.06), and the ability to purchase products via the Internet (the mean assessment of the importance of a feature is 4.02). The lowest are assessed completeness of deliveries - compliance of delivery with the order (the mean assessment of the importance of a feature is 3.98), and reliability of deliveries in terms of time, quantity and quality of delivered products (the mean assessment of the importance of a feature is 3.92). When taking into account analyzed provinces separately different features of the offer are assessed the highest. According to cooperatives from Świętokrzyskie Province the most important for consumers is ensuring a convenient time to purchase the product (the mean assessment of the importance of a feature is 4.33), and for cooperatives from Małopolskie Province is the flexibility of delivery in terms of time, size, range and delivery method (the mean assessment of the importance of a feature is 4.50). In the same time cooperatives from both provinces agree in assessment of the least important feature for consumers, which is the reliability of deliveries in terms of time, quantity and quality of delivered products. The mean assessment of the importance of this feature is 3.92 in the opinion of cooperatives from Świętokrzyskie Province and 3.58 according to cooperatives from Małopolskie Province. In assessing other features of the offer both provinces differ. Research result also show that cooperatives from Małopolskie Province rather lower assessed the validity of the features of the offer for their customers than cooperatives from Świętokrzyskie Province despite these provinces adjacent to each other.

\section{References}

1. Altkorn, J. (2004). Podstawy marketingu. Kraków: Instytut Marketingu.

2. Blythe, J. (2005). Essentials of Marketing. Harlow: Prentice Hall.

3. Burda, A., (2012). Redefining the Role of Distribution and its Relationship with Production. Economy, Commerce and Tourism Series, Vol. IX, pp. 80-92.

4. Burnett, J. (2008). Core Concepts of Marketing. Zurich: Global Text Project.

5. Drummond, G., Ensor, J., Ashford, R. (2008). Strategic Marketing: Planning and Control. Oxford: Butterworth-Heinemann.

6. Ehmke, C., Fulton, J., Lusk, J. (2007). Marketing's Four P's: First Steps for New Entrepreneurs. Purdue Extension: Knowledge to Go. Purdue University, No. EC-730, pp. 1-12. 
7. Große-Brockhoff, M., Klumpp, M., Krome, D. (2011). Logistics capacity management A theoretical review and applications to outbound logistics. Essen: Institut für Logistik- \& Dienstleistungsmanagement der FOM Hochschule für Oekonomie \& Management.

8. Kłeczek, R. (1992). Marketing. Jak to się robi. Wrocław: Zakład Narodowy im. Ossolińskich.

9. Konieczna, I. (2014). Ważność cech oferty dla klienta w obszarze dystrybucji z punktu widzenia spółdzielni mleczarskich $\mathrm{z}$ województwa świętokrzyskiego. Logistyka, No. 6 , pp. 14354-14364.

10. Krawczyk, S. (2000). Logistyka w zarządzaniu marketingiem. Wrocław: Wydawnictwo Akademii Ekonomicznej.

11. Lourenço, H.R. (2005). Logistics Management. An Opportunity for Metaheuristics. In: C. Rego, B. Alidaee (Eds.), Metaheuristic Optimization via Memory and Evolution Tabu Search and Scatter Search. Series: Operations Research/Computer Science Interfaces Series, Vol. 30, pp. 329-356.

12. Lukinykh, Lukinykh (2015). Algorithm for the Procurement and Inventory Management in the Distribution Supply Chain. Business Logistics in Modern Management - Proceedings of The $15^{\text {th }}$ International Scientific Conference. Osijek: JOSIP Juraj Strossmayer University of Osijek, pp. 79-91.

13. Sierpińska, M., Jachna, T. (2007). Ocena przedsiębiorstwa wedtug standardów światowych. Warszawa: PWN.

14. Vučemilović, V. (2015). Distribution Channels of Major Construction Materials. Business Logistics in Modern Management - Proceedings of The $15^{\text {th }}$ International Scientific Conference. Osijek: JOSIP Juraj Strossmayer University Of Osijek, pp. 131-141. 